\title{
Coccidioidomycosis in Biopsies with Presumptive Diagnosis of Malignancy in Dogs: Report of Three Cases and Comparative Discussion of Published Reports
}

\author{
Rafael Ramírez-Romero • Rolando Antonio Silva-Pérez • Jorge Lara-Arias • \\ Cecilia Ramírez-Hernández • Iván Alberto Marino-Martínez • \\ Álvaro Barbosa-Quintana · Alfonso López-Mayagoitia
}

Received: 18 May 2015/ Accepted: 16 September 2015/Published online: 29 September 2015

(C) The Author(s) 2015. This article is published with open access at Springerlink.com

\begin{abstract}
Coccidioidomycosis is a respiratory fungal infection with occasional systemic dissemination. The disseminated coccidioidomycosis is considered a multifaceted disease. In medicine, disseminated coccidioidomycosis is included within a group of infectious diseases that have been referred as the great imitators. In many cases, malignancies are included in the presumptive diagnosis. In veterinary medicine, disseminated coccidioidomycosis is common in dogs. Nonetheless, despite of being a diagnostic dilemma, disseminated coccidioidomycosis is underestimated and frequently not included into differentials, even in endemic zones. Herein, we describe three cases of granulomatous inflammation caused by Coccidioides spp. which were masquerading malignancies in dogs $(0.39 \%)$. The presumptive diagnoses in these cases were osteosarcoma, lymphoma and neurofibroma, respectively. A PCR assay employing tissues in paraffin blocks resulted positive for $C$. posadasii in
\end{abstract}

R. Ramírez-Romero $(\bowtie) \cdot$ R. A. Silva-Pérez •

C. Ramírez-Hernández

Posgrado Conjunto Agronomía-Veterinaria, Facultad de

Medicina Veterinaria y Zootecnia, Campus de Ciencias

Agropecuarias, Universidad Autónoma de Nuevo León,

Av. Francisco Villa s/n, Ex-Hacienda el Canadá,

C.P. 66050 Gral. Escobedo, N.L., México

e-mail: raramirez@prodigy.net.mx

\section{J. Lara-Arias}

Banco de Hueso y Tejidos, Hospital Universitario "Dr. José E. González”, Universidad Autónoma de Nuevo León, Monterrey, N.L., México one of these cases. A comparative discussion on the ambiguous clinic-pathological presentation of disseminated coccidioidomycosis in dogs and humans is included.

Keywords Coccidioidomycosis $\cdot$ Dog $\cdot$ Neoplasia $\cdot$ Surgical pathology $\cdot$ Mexico

\section{Introduction}

Neoplasia is of major relevance in both medicine and veterinary medicine. For diagnosis, even nowadays when molecular procedures are commonly employed, surgical pathology is irreplaceable [1]. Slide interpretation by a pathologist is still the most useful and precise procedure for malignancies diagnosis [1]. Clinicians require the pathologist to offer a prognosis in a neoplasm [1]. Furthermore, histopathology can also be the guidance if the presumption was equivocal,

\section{A. Marino-Martínez \\ Centro de Investigación y Desarrollo en Ciencias de la Salud (CIDICS), Universidad Autónoma de Nuevo León, Monterrey, N.L., México}
Á. Barbosa-Quintana
Departamento de Anatomía Patológica, Hospital Universitario, Facultad de Medicina, Universidad Autónoma de Nuevo León, Monterrey, N.L., México
A. López-Mayagoitia
Atlantic Veterinary College, University of Prince Edward Island, Charlottetown, PE, Canada


such as in neoplasm-like cases of coccidioidomycosis [2]. Indeed, histopathology is a standard gold test for coccidioidomycosis [2,3]. Identification by molecular procedures is not available routinely for coccidioidomycosis [2, 4]. Nowadays, there are few reference laboratories employing PCR to clinical samples $[2,4,5]$. Fortunately, for diagnosis, histopathology is still superior to molecular techniques such as PCR [2, $4,5]$. In fact when tissue is available, histopathology is the first procedure routinely employed to diagnose all systemic fungal infections [2-4].

Coccidioidomycosis is a respiratory and systemic mycotic disease, highly relevant in public health [68]. The specialized requirements of Coccidioides spp. confine the fungus to limited zones of high endemicity. These zones are characterized by arid alkaline lands with limited rainfalls, high summer temperatures and few freezing days in winter. Soils with these characteristics prevail in the southern USA, particularly in the "lower Sonoran life zone" [6,9]. The states of Arizona and California are considered high endemic areas. However, New Mexico and Texas are also emerging [6, 7]. In Mexico, coccidioidomycosis is most prevalent in the states neighboring USA [3, 8, 9]. Infections with Coccidioides immitis are predominant in the Northwest, whereas in Northeast Coccidioides posadasii is more prevalent [10]. The state of Nuevo León in the Northeast, bordering with Texas, USA, is the state with the highest incidence of coccidioidomycosis in humans in Mexico [8]. All of the cases herein included belong to dogs from the city of Monterrey, principal city of Nuevo Leon, Mexico.

We report here three cases of dogs clinically suspected of having neoplasia; however, surgical biopsies confirmed that the problem was unsuspected granulomatous inflammation caused by disseminated coccidioidomycosis.

The material herein included corresponds to 765 dog biopsies with presumptive diagnosis of neoplasm between April 1, 2010, and March 31, 2015. Samples were submitted by veterinarians with private practice in small animals in Monterrey, Mexico. Tissues were submitted in $10 \%$ buffered formalin. Histology procedures were conventional with routine $\mathrm{H} \& \mathrm{E}$ stain and in the cases herein presented also periodic acid Schiff (PAS) and Gomori methenamine silver (GMS) stains were employed.

Among the 765 biopsies with presumptive diagnoses of neoplasm, three cases of coccidioidomycosis were recognized $(3 / 765 \times 100=0.39 \%)$. The 762 cases of neoplasia confirmed by histopathology (762/ $765 \times 100=99.60 \%)$ reveal a higher correspondence between biopsies with presumption of malignancy and histopathological confirmation. Therefore, coccidioidomycosis is reasonably unexpected in biopsies with clinical presumption of neoplasia. These three coccidioidomycosis cases are herein described.

\section{Case 1}

An 18-month-old male German shepherd was presented to the veterinarian for progressive weight loss and weakness that eventually lead to prostration. During clinical examination, the veterinarian noticed that the masseter muscles were atrophied and several painless nodular lesions $(0.5-1 \mathrm{~cm})$ involving the tarsal, phalanges and lumbar regions were evident. Radiographs of affected bones revealed low-density proliferative osseous changes which were interpreted as consistent with neoplasm. The presumptive diagnosis was osteosarcoma. Six small $(0.3-0.5 \mathrm{~cm})$ tissue samples were taken from affected areas, fixed in $10 \%$ buffered formalin and submitted to histopathological studies. Microscopically, all biopsies showed extensive connective tissue proliferation heavily infiltrated with macrophages, giant multinucleated cells and some neutrophils and lymphocytes. Most remarkable was the presence of numerous conspicuous PAS- and GMS-positive oval spherules (10-40 $\mu \mathrm{m}$ diameter) with thick refractile walls containing small bodies (endospores). Most of these spherules were intact, but few of them were broken releasing the endospores in the surroundings. These spherules were interpreted as fungal organisms with morphologic features of $\mathrm{Coc}$ cidioides spp. Morphologic diagnosis was severe granulomatous periostitis and deep dermatitis, chronic, locally extensive with numerous intralesional fungal organisms consistent with Coccidioides spp.

\section{Case 2}

A 12-month-old female Boxer was presented to the veterinarian for a progressive swelling of the left hind leg. On physical examination, a movable non-painful mass was recognized in the popliteal region. No other changes were noticed during the physical examination. The veterinarian interpreted the growth on the hind limb as an enlarged popliteal lymph node. The 
whole lymph node was surgically excised. On palpation, the node had a soft texture with some hemorrhages on cut surface. The presumptive diagnosis was lymphoma. The lymph node was fixed in $10 \%$ buffered formalin and submitted for histopathological examination. Microscopically, the specimen was a lymph node in which the histological architecture was notably effaced by fibrosis and an intense infiltration of macrophages, giant multinucleated cells, lymphocytes, plasma cells and neutrophils. The inflammatory response was more evident at the hilum of the node where fibroplasia was also marked. Embedded in this granulomatous reaction there were numerous PAS-/ GMS-positive spherules ranging in size from 10 to $40 \mu \mathrm{m}$ in diameter. These fungal structures had thick birefringent walls containing round endospores (Fig. 1, inset). Morphologic diagnosis was severe granulomatous/pyogranulomatous lymphadenitis, chronic, multifocal to coalescent with numerous intralesional fungal organisms consistent with $\mathrm{Coc}$ cidioides spp.

\section{Case 3}

A mature (age unknown), female Labrador retriever with a several months history of progressive weakness, ataxia and prostration was presented to the veterinary clinic. On physical examination, the dog

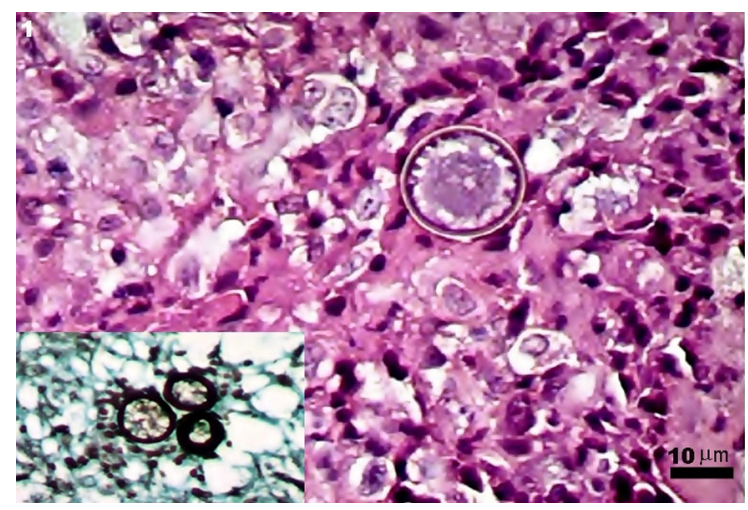

Fig. 1 Case 3, dog with suspicion of neurofibroma. There is one spherule with thick and refractile cell wall. The endospores contained within are ill defined. The inflammatory reaction is composed by epithelioid macrophages and lymphocytes; the proliferation of fibrous connective tissue is prominent. H\&E bar $10 \mu \mathrm{m}$. The inset depicts the special stain with three organisms in a pyogranulomatous reaction in case 2 . GMS. The image is representative of all of the cases here included appeared in poor condition. Moreover, a subcutaneous non-ulcerated firm mass $(7.0 \times 6.0 \mathrm{~cm})$ was noted on the left side thorax (ribs 9-11). This mass was nonpainful and non-movable. Physical exam also revealed weakness and hypoesthesia affecting the left hind leg. Radiographic study exposed locally extensive osteolysis of affected ribs. The mass was partially removed and submitted for histopathological examination. The presumptive diagnosis was neurofibroma. Microscopically, the specimen was composed by skin and subcutaneous tissue severe and diffusely infiltrated with macrophages, lymphocytes, plasma cells, giant multinucleated cells and few neutrophils. These inflammatory infiltrates were forming well-delineated granulomas with necrotic centers surrounded by phagocytic cells and encircled with a tick band of connective fibrous tissue. These granulomatous lesions also contained numerous PAS-/GMS-positive fungal structures morphologically consistent with Coccidioides spp. (Fig. 1). Morphologic diagnosis was severe granulomatous deep dermatitis, fasciitis and periostitis (ribs 9-11), locally extensive, with numerous intralesional fungal structures compatible with Coccidioides spp.

\section{Molecular Procedures}

For PCR, total DNA was extracted from the paraffinembedded tissues using the ReliaPrep ${ }^{\mathrm{TM}}$ FFPE gDNA Miniprep System (Promega Corp.). Paraffin blocks with more presence of Coccidioides spp. were selected. The primer set was Coi9-1F (5'-TACGGTGTAATCCCG ATACA-3') and Coi9-1R (5'GGTCTGAATGATCTGACGCA-3 ${ }^{\prime}$ ) as previously reported [11]. PCR conditions were as follows: 1 cycle at $94{ }^{\circ} \mathrm{C}$ for $3^{\prime \prime}$ followed by 35 cycles at $94{ }^{\circ} \mathrm{C}$ for $30^{\prime}$, at $60^{\circ} \mathrm{C}$ for $30^{\prime}$ and at $72^{\circ} \mathrm{C}$ for $45^{\prime}$ with a final step at $72{ }^{\circ} \mathrm{C}$ for $3^{\prime \prime}$ [11]. Unfortunately, tissues were available only from cases 2 and 3 ; the blocks included were those with major evidence of Coccidioides spp. in tissues (cases 2 and 3). The amplicons reported for the selected primers are $720 \mathrm{bp}$ for $C$. immitis and 634 bp for C. posadasii [11-13]. Due to scarcity of tissue in paraffin blocks, the isolated DNA concentration was not enough to amplify the sample 1 (case 2). However, it was possible to amplify the second sample (case 3) with an approximately 634-bp amplicon, corresponding to $C$. posadasii according to previous reports [11-13] (Fig. 2). 


\section{Discussion}

Coccidioidomycosis is a renowned clinical impersonator of malignancy in human and veterinary medicine [5, 14-17]. A comparative list of organs affected with coccidioidomycosis masquerading malignancy in human and dogs is summarized in Table 1. When veterinary practitioners are confronted with the classic algorithm of neoplasm/inflammation, histopathology in a biopsy is by far the most accurate method [2]. Furthermore, histopathology is the procedure of choice for systemic fungal infections [2, 4].

In reviewing the literature, it was surprising to find only two reports in dogs in which coccidioidomycosis was masquerading malignancies. One case was from a dog erroneously diagnosed by the attending clinician with a testicular tumor [14], and another two dogs with a suspected heart-base tumor [17]. Systemic mycosis including coccidioidomycosis should be at top differential diagnosis in dogs with chronic debilitating disease, particularly if there is evidence of generalized lymphadenopathy, lameness, skin nodules or ulcers that do not heal. Another crucial factor is if the dog has been living or has travelled to zones where coccidioidomycosis is known to be endemic $[16,38]$. It is

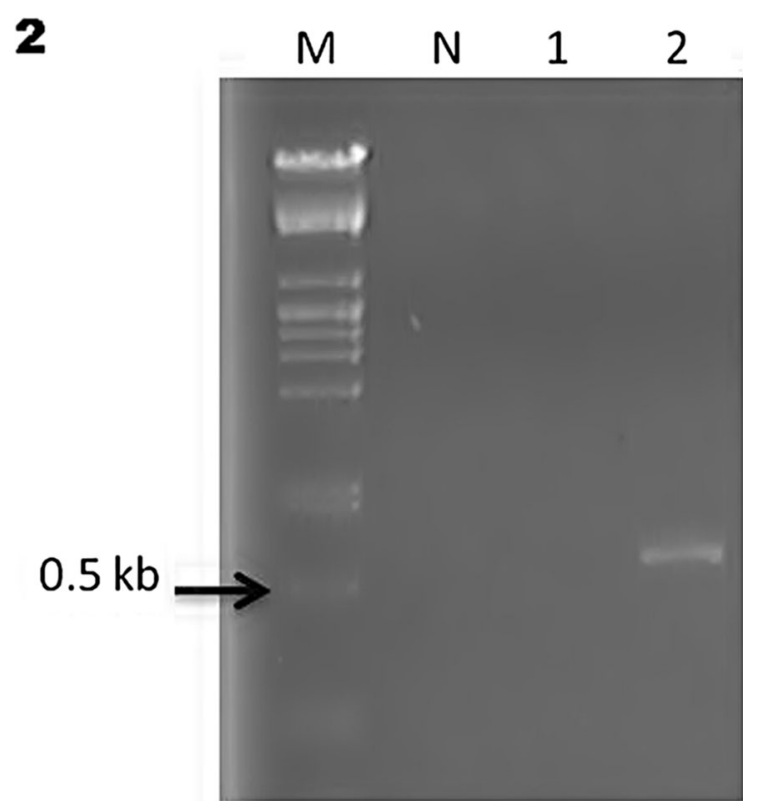

Fig. 2 PCR amplification from two paraffin-embedded tissues. Lane $M$, DNA molecular weight marker, lane $N$, negative control. Lane 1, sample case 2 and lane 2, sample case 3 with an amplicon of $634 \mathrm{pb}$. The result corresponds to C. posadasii noteworthy to mention that neoplasm and coccidioidomycosis can simultaneously occur in the same dog. A good example of this type of comorbidity was reported in a mature dog with history of lethargy, inappetence and generalized lymphadenopathy diagnosed afterward with disseminated coccidioidomycosis and multisystemic lymphoma [20]. Interestingly, the clinical signs and lymph node enlargement in this dog improved notably after antifungal treatment and chemotherapy [20].

Human coccidioidomycosis is highly prevalent in the northern Mexico particularly in regions neighboring the USA. According to several epidemiological surveys conducted between 1994 and 2005, the prevalence of Coccidioides spp. infection recognized by intradermal reaction, ranged geographically from $9.2 \%$ in Tijuana, Baja California to $93 \%$ in Matamoros, Coahuila [8]. The overall rate calculated for Mexico is $1.6 \%$ [8]. As it may be expected, the prevalence rates in northern Mexico are comparable to those reported for humans in the southern USA [6, 7].

It is worth noting that the three dogs reported in this study were from Nuevo Leon, the Mexican state with the highest prevalence of human coccidioidomycosis in the country. A large study conducted between 1983 and 2000 in 4598 autopsies in Nuevo Leon showed that $31(0.67 \%)$ of the cadavers had evidence of coccidioidomycosis [39]. Although the studies are different, the higher rate of cases in human autopsies is only the double than the positive biopsies encountered here in much less samples. Since the mode of infection and lesions are similar in dogs and humans, the dog has been considered as sentinel as well as animal model for this disease [40-42].

The granulomatous lesions incited by Coccidioides spp. in dog are dominated by $\mathrm{T}$ lymphocytes [43]. However, the inflammatory reaction is not specific and comparable lesions can also be caused by other fungal and algal infections that share some histopathological images with coccidioidomycosis, such as paracoccidioidomycosis [44], blastomycosis [45], protothecosis [46] and chlorellosis [47], that naturally occur in the dog. Nonetheless for all of these infections, if tissue is available, histopathology is the elected procedure [2]. On the other hand, molecular procedures would probably be the upcoming procedures, but nowadays histopathology is the most accurate diagnostic tool. In the present study, the difficulties to work with paraffinembedded tissues were solved not easily and this has 
Table 1 Comparative cases of coccidioidomycosis in humans and dogs with presumptive diagnosis of neoplasia

\begin{tabular}{|c|c|c|c|}
\hline $\begin{array}{l}\text { Human } \\
\text { beings } \\
\text { Tissues, } \\
\text { organs }\end{array}$ & References & $\begin{array}{l}\text { Dogs } \\
\text { Tissues, } \\
\text { organs }\end{array}$ & References \\
\hline Lymphoid & $\begin{array}{l}\text { Aviles-Salas et al. [18]; suspected lymphoma; } \\
\text { Cannella and Vinetz [19]; suspected lymphoma }\end{array}$ & Lymphoid & $\begin{array}{l}\text { Jeroski [20]; coccidioidomycosis concomitant } \\
\text { with disseminated lymphoma } \\
\text { [*] Suspected lymphoma case } 2 \text { herein } \\
\text { included }\end{array}$ \\
\hline Bone & $\begin{array}{l}\text { Arora et al. [21]; multiple myeloma or bone } \\
\text { metastasis; } \\
\text { Caraway et al. [22]; primary bone neoplasm } \\
\text { Li et al. [23]; suspected primary bone neoplasm } \\
\text { Smitherman and Ritter [24]; presumptive pelvic } \\
\text { sarcoma } \\
\text { Huang et al. [25]; presumptive metacarpal } \\
\text { enchondroma }\end{array}$ & Bone & $\begin{array}{l}\text { Shubitz and Dial [16]; suspected bone } \\
\text { neoplasm } \\
{[*] \text { Suspected osteosarcoma case } 1 \text { herein }} \\
\text { included }\end{array}$ \\
\hline Lung & $\begin{array}{l}\text { Petrini et al. [26]; suspected lung neoplasm } \\
\text { Guimarães et al. [27]; presumptive pulmonary } \\
\text { neoplasm } \\
\text { Gazzoni et al. [28]; presumptive lung primary } \\
\text { neoplasms } \\
\text { Stieglitz et al. [29]; suspected Ewing sarcoma } \\
\text { metastasis to lung }\end{array}$ & Lung & $\begin{array}{l}\text { Shubitz and Dial [16]; suspected metastatic } \\
\text { neoplasms }\end{array}$ \\
\hline Gonads & $\begin{array}{l}\text { Halsey et al. [30]; presumptive testicle neoplasm } \\
\text { Ellis et al. [31]; suspected ovary malignancy }\end{array}$ & Gonads & $\begin{array}{l}\text { Ramírez-Romero et al. [14]; suspected } \\
\text { primary neoplasm in testicle }\end{array}$ \\
\hline Brain & $\begin{array}{l}\text { Komotar and Clatterbuck [32]; plaque } \\
\text { meningioma }\end{array}$ & Brain & $\begin{array}{l}\text { Bentley et al. [33]; suspected neoplastic } \\
\text { masses }\end{array}$ \\
\hline Skin subcutis & $\begin{array}{l}\text { Schwartz and Lamberts [34]; suspected squamous } \\
\text { cell carcinoma } \\
\text { Crum [35]; suspected mycosis fungoides } \\
\text { Hirschmann [36]; since the original descriptions } \\
\text { mycosis fungoides was suspected }\end{array}$ & Skin subcutis & $\begin{array}{l}{[*] \text { Herein, associated to ribs; suspected }} \\
\text { neurofibroma, case } 3\end{array}$ \\
\hline Abdomen & Eyer, et al. [37]; suspected peritoneal malignancy & & \\
\hline
\end{tabular}

been mentioned recently [4]. However, the positive result in the tissue from case 3 correspondent with Coccidioides posadasii is very interesting and is in accordance with previous studies which report this species as more prevalent in the Northeast in Mexico and the corresponding Southeast of USA [6, 7]. Future studies are required to characterize the species involved in natural cases of coccidioidomycosis in dogs in Nuevo Leon, Mexico.

Despite of the few cases encountered here, coccidioidomycosis has to be considered into differential diagnosis of proliferative lesions suspected of neoplasm, particularly in Nuevo Leon, state included in the endemic zone of Mexico.

Acknowledgments Rolando Antonio Silva Pérez is supported by CONACYT.

\section{Compliance with Ethical Standards}

Conflict of interest The authors declare that they have no competing interests.

Open Access This article is distributed under the terms of the Creative Commons Attribution 4.0 International License (http:// creativecommons.org/licenses/by/4.0/), which permits unrestricted 
use, distribution, and reproduction in any medium, provided you give appropriate credit to the original author(s) and the source, provide a link to the Creative Commons license, and indicate if changes were made.

\section{References}

1. Rosai J. Why microscopy will remain a cornerstone of surgical pathology. Lab Investig. 2007;87(5):403-8.

2. Guarner J, Brandt ME. Histopathologic diagnosis of fungal infections in the 21st century. Clin Microbiol Rev. 2011;24(2):247-80. doi:10.1128/CMR.00053-10.

3. Laniado-Laborin R, Alcantar-Schramm JM, CazaresAdame R. Coccidioidomycosis: an update. Curr Fungal Infect Rep. 2012;. doi:10.1007/s12281-012-0084-z.

4. Frickmann H, Loderstaedt U, Racz P, Tenner-Racz K, Eggert P, Haeupler A, Bialek R, Hagen RM. Detection of tropical fungi in formalin-fixed, paraffin-embedded tissue: Still an indication for microscopy in times of sequencebased diagnosis? Biomed Res Int. 2015; 2015:938721. doi: 10.1155/2015/938721 (Epub 19 Apr 2015).

5. Malo J, Luraschi-Monjagatta C, Wolk DM, Thompson R, Hage CA, Knox KS. Update on the diagnosis of pulmonary coccidioidomycosis. Ann Am Thorac Soc. 2014;11(2): 243-53. doi:10.1513/AnnalsATS.201308-286FR.

6. Brown J, Benedict K, Park BJ, Thompson GR 3rd. Coccidioidomycosis: epidemiology. Clin Epidemiol. 2013; 25(5):185-97.

7. Hector RF, Rutherford GW, Tsang CA, Erhart LM, McCotter O, Anderson SM, et al. The public health impact of coccidioidomycosis in Arizona and California. Int $\mathbf{J}$ Environ Res Public Health. 2011;8(4):1150-73.

8. Baptista Rosas RC, Riquelme M. Epidemiología de la coccidioidomicosis en México. Rev Iberoam Micol. 2007; 24(2):100-5.

9. Fisher FS, Bultman MW, Johnson SM, Pappagianis D, Zaborsky E. Coccidioides niches and habitat parameters in the southwestern United States: a matter of scale. Ann N Y Acad Sci. 2007;1111:47-72. doi:10.1196/annals.1406.031.

10. Luna-Isaac JA, Muñiz-Salazar R, Baptista-Rosas RC, Enríquez-Paredes LM, Castañón-Olivares LR, ContrerasPérez C, et al. Genetic analysis of the endemic fungal pathogens Coccidioides posadasii and Coccidioides immitis in Mexico. Med Mycol. 2014;52(2):156-66.

11. Umeyama T, Sano A, Kamei K, Niimi M, Nishimura K, Uehara Y. Novel approach to designing primers for identification and distinction of the human pathogenic fungi Coccidioides immitis and Coccidioides posadasii by PCR amplification. J Clin Microbiol. 2006;44(5):1859-62.

12. Tintelnot K, De Hoog GS, Antweiler E, Losert H, Seibold M, Brandt MA, et al. Taxonomic and diagnostic markers for identification of Coccidioides immitis and Coccidioides posadasii. Med Mycol. 2007;45(5):385-93.

13. de Cordeiro RA, e Silva KR, Brilhante RS, Moura FB, Duarte NF, Marques FJ, et al. Coccidioides posadasii infection in bats, Brazil. Emerg Infect Dis. 2012;18(4): 668-70. doi:10.3201/eid1804.111641.

14. Ramirez-Romero R, Nevárez-Garza AM, Frausto-Rodriguez JA, Andrade-Manjarrez EE. Coccidioidomicosis diseminada en el perro: presentación de un caso. Vet Méx. 1991;22:181-4.

15. Oldfield EC III, Olson PE, Bone WD, Bradshaw DA, Martin CR. Coccidioidomycosis presenting as neoplasia: another great imitator disease. Infect Dis Clin Pract. 1995;4:87-92.

16. Shubitz LF, Dial SM. Coccidioidomycosis: a diagnostic challenge. Clin Tech Small Anim Pract. 2005;20(4):220-6.

17. Ajithdoss DK, Trainor KE, Snyder KD, Bridges CH, Langohr IM, Kiupel M, Porter BF. Coccidioidomycosis presenting as a heart base mass in two dogs. J Comp Pathol. 2011;145(2-3):132-7. doi:10.1016/j.jcpa.2010.12.014.

18. Avilés-Salas A, Quintero-Cuadra Y, Cornejo-Juárez P. Coccidioidomicosis extrapulmonar. Presentación de un caso y revisión de la literatura. Rev Child Infect. 2007;24(5): 398-401.

19. Cannella AP, Vinetz JM. A young man evaluated for suspicion of lymphoma. Am J Trop Med Hyg. 2014;91(3):440-1. doi:10.4269/ajtmh.14-0084.

20. Jeroski A. Multicentric lymphoma and disseminated coccidioidomycosis in a dog. Can Vet J. 2003;44:62-4.

21. Arora NP, Taneja V, Reyessacin C, Bhanot R, Natesan SK. Coccidioidomycosis masquerading as malignancy. BMJ Case Rep. 2012;. doi:10.1136/bcr.12.2011.5357.

22. Caraway NP, Fanning CV, Stewart JM, Tarrand JJ, Weber KL. Coccidioidomycosis osteomyelitis masquerading as a bone tumor. A report of 2 cases. Acta Cytol. 2003;47(5): 777-82.

23. Li YC, Calvert G, Hanrahan CJ, Jones KB, Randall RL. Coccidiomycosis infection of the patella mimicking a neoplasm-two case reports. BMC Med Imaging. 2014;18(14):8. doi:10.1186/1471-2342-14-8.

24. Smitherman K, Ritter M. Coccidioidomycosis mimicking pelvic sarcoma. J Hosp Med. 2014; 9 (suppl 2). http://www. shmabstracts.com/abstract/coccidioidomycosismimicking-pelvic-sarcoma/.

25. Huang JI, Seeger LL, Jones NF. Coccidioidomycosis fungal infection in the hand mimicking a metacarpal enchondroma. J Hand Surg Br. 2000;25(5):475-7.

26. Petrini B, Sköld CM, Bronner U, Elmberger G. Coccidioidomycosis mimicking lung cancer. Respiration. 2003;70(6):651-4.

27. Guimarães MD, Marchiori E, Meirelles GSP, Hochhegger B, Pinheiro Santana PR, Gross JL, Vieira Bitencourt AG, Piyaporn B, Barco Godoy MC. Fungal infection mimicking pulmonary malignancy: clinical and radiological characteristics. Lung. 2013;191(6):655-62.

28. Gazzoni FF, Severo LC, Marchiori E, Irion KL, Guimarães MD, Godoy MC, Sartori AP, Hochhegger B. Fungal diseases mimicking primary lung cancer: radiologic-pathologic correlation. Mycoses 2014; 57(4):197-208. doi: 10. 1111/myc.12150 (Epub 22 Oct 2013).

29. Stieglitz E, Hsiang MS, Simko JP, Hirose S, Goldsby RE. Pulmonary coccidiomycosis masquerading as refractory metastatic Ewing sarcoma. J Pediatr Hematol Oncol. 2014;36(1):e57-60. doi:10.1097/MPH.0b013e318286d4fd.

30. Halsey ES, Rasnake MS, Hospenthal DR. Coccidioidomycosis of the male reproductive tract. Mycopathologia. 2005;159(2):199-204.

31. Ellis MW, Dooley DP, Sundborg MJ, Joiner LL, Kost ER. Coccidioidomycosis mimicking ovarian cancer. Obstet Gynecol. 2004;104(5 Pt 2):1177-9. 
32. Komotar RJ, Clatterbuck RE. Coccidioidomycosis of the brain, mimicking en plaque meningioma. J Neurol Neurosurg Psychiatry. 2003;74(6):806.

33. Bentley RT, Heng HG, Thompson C, Lee CS, Kroll RA, Roy ME, Marini L, Heo J, Wigle WL. Magnetic resonance imaging features and outcome for solitary central nervous system coccidioides granulomas in $11 \mathrm{dogs}$ and cats. Vet Radiol Ultrasound. 2015; doi:10.1111/vru.12258.

34. Schwartz RA, Lamberts RJ. Isolated nodular cutaneous coccidioidomycosis. The initial manifestation of disseminated disease. J Am Acad Dermatol. 1981;4(1):38-46.

35. Crum NF. Disseminated coccidioidomycosis with cutaneous lesions clinically mimicking mycosis fungoides. Int $\mathrm{J}$ Dermatol. 2005;44(11):958-60.

36. Hirschmann JV. The early history of coccidioidomycosis: 1892-1945. Clin Infect Dis. 2007;44(9):1202-7.

37. Eyer BA, Qayyum A, Westphalen AC, Yeh BM, Joe BN, Coakley FV. Peritoneal coccidioidomycosis: a potential CT mimic of peritoneal malignancy. Abdom Imaging. 2004;29(4): 505-6.

38. Graupmann-Kuzma A, Valentine BA, Shubitz LF, Dial SM, Watrous B, Tornquist SJ. Coccidioidomycosis in dogs and cats: a review. J Am Anim Hosp Assoc. 2008;44(5):226-35.

39. Calderón-Garcidueñas AL, Piña-Osuna K, Leal-Moreno AM, López-Cárdenas A, Cerda-Flores RM. Características clinicopatológicas y distribución del número de autopsias de fallecidos por coccidioidomicosis en un hospital de referencia del noreste de México. Gac Med Mex. 2004;140(4): 399-404.

40. Gautam R, Srinath I, Clavijo A, Szonyi B, Bani-Yaghoub M, Park S, Ivanek R. Identifying areas of high risk of human exposure to coccidioidomycosis in Texas using serology data from dogs. Zoonoses Public Health. 2013;60(2): 174-81.

41. Shubitz LF. Comparative aspects of coccidioidomycosis in animals and humans. Ann N Y Acad Sci. 2007;1111: 395-403.

42. Wanke B, Lazera M, Monteiro PC, Lima FC, Leal MJ, Ferreira Filho PL, Kaufman L, Pinner RW, Ajello L. Investigation of an outbreak of endemic coccidioidomycosis in Brazil's northeastern state of Piauí with a review of the occurrence and distribution of Coccidioides immitis in three other Brazilian states. Mycopathologia. 1999;148(2):57-67.

43. Shubitz LF, Dial SM, Galgiani JN. T-lymphocyte predominance in lesions of canine coccidioidomycosis. Vet Pathol. 2011;48(5):1008-11.

44. de Farias MR, Condas LA, Ribeiro MG, Bosco Sde M, Muro MD, Werner J, Theodoro RC, Bagagli E, Marques SA, Franco M. Paracoccidioidomycosis in a dog: case report of generalized lymphadenomegaly. Mycopathologia 2011; 172(2):147-52. doi: 10.1007/s11046-011-9412-z (Epub 20 Mar 2011).

45. Parker K, Snead E, Anthony J, Silver T. Oronasal blastomycosis in a golden retriever. Can Vet J. 2013;54(8): 748-52.

46. Vince AR, Pinard C, Ogilvie AT, Tan EO, Abrams-Ogg AC. Protothecosis in a dog. Can Vet J. 2014;55(10):950-4.

47. Quigley RR, Knowles KE, Johnson GC. Disseminated chlorellosis in a dog. Vet Pathol. 2009; 46(3):439-43. doi: 10.1354/vp.08-VP-0142-Q-BC (Epub 27 Jan 2009). 